\title{
AREAL RELATIONS OF INDO-EUROPEAN LOANWORDS IN FINNIC DIALECTS
}

\author{
Vilja Oja \\ Institute of the Estonian Language
}

\begin{abstract}
The areas of the distribution of Indo-European loanwords in Finnic dialects are described on many lexical maps of the Atlas Linguarum Fennicarum and the Atlas Linguarum Europae. The maps of those atlases offer an opportunity to follow the post-formational contacts of the languages. The analysis of the spread of loanwords makes it possible to find the main routes and centres of Indo-European innovations in Finnic dialects and discuss the reasons for the different sources of the influences. Sometimes, the Finnic area has been a boundary zone for several widespread IndoEuropean stems coming from different directions. Often the area distribution of dialect words is etymologically suggestive, but the source language depends on the concept. The differences in the use of stems with the same Indo-European origin in different Finnic languages may, at least partly, be due to the words having been borrowed at different times and from different donor languages.
\end{abstract}

Keywords: dialect vocabulary, Indo-European loanwords, linguistic atlases, Finnic languages

DOI: http://dx.doi.org/10.12697/jeful.2014.5.2.04

\section{Introduction}

All of the neighbours of the Finnic branch of the Uralic language family speak Indo-European languages: Germanic languages are spoken to the north and west of the Finnic area, Baltic languages to the south of it, and Slavic languages to the east of the area. Such a position means close contacts with several Indo-European languages. The contacts between the neighbouring languages are vividly shown in linguistic atlases. The dialect vocabulary of all Finnic languages is mapped in two atlases: in the Atlas of European languages Atlas Linguarum Europae (ALE) and in the Atlas of Finnic languages Atlas Linguarum Fennicarum (ALFE). Some results of the analysis of the areal relations between Indo-European loanwords in Finnic are described in this article, mainly based on the data in the ALE and ALFE maps. Addi- 
tional data have been drawn from the unilingual atlases compiled earlier on the basis of Finnish, Estonian and Karelian dialects (EMA, Kettunen 1940, VEMA, Leskinen 1992 and Bubrih et al. 1997), from literature and from two collections of the Finnic dialect vocabulary: the Lexical Archive of Estonian Dialects and Finno-Ugric Languages (EMSUKA), housed at the Institute of the Estonian Language in Tallinn, and the Lexical Archive of Finnish Dialects (SMSA), housed at the Research Institute for the Languages of Finland in Helsinki.

\section{Atlas Linguarum Europae and Atlas Linguarum Fennicarum}

Both the Atlas Linguarum Europae (ALE) and Atlas Linguarum Fennicarum (ALFE) were compiled by international teams consisting of specialists in different European or Finnic languages and dialects. The first questionnaire of the ALE contains 546 lexical questions (ALEQ). The questionnaire of the ALFE contains 318 lexical questions (IMSK). Dialect material for the ALE was collected in 2631 localities in Europe. The Finnic languages are represented by 263 patois, which is one-tenth of the ALE total. The maximal density of the ALE mapping points is the same as the minimal density of ALFE: 1 per $2000 \mathrm{~km}^{2}$. An ALE map represents only one equivalent of the data for each mapping point, while ALFE has no such restriction. Up to now, eight ALE fascicles have been published, containing maps and commentaries that describe the vocabulary used for 90 concepts. ${ }^{1}$ The final part of the three-volume Finnic Atlas (ALFE 3) was published in 2010. Some of the notions are mapped in both atlases, but the presentation of the material in the ALFE maps is either more detailed or is emphasised differently than in ALE. ALFE is focused mainly on Finnic-specific problems and the relationship between Finnic languages.

The linguistic data described in these atlases represent the situation of dialect speech in the 19th and 20th centuries. The atlases contain various kinds of maps, mostly onomasiologic and motivational maps, but also other linguistic phenomena, such as semantics or phonetic and morphologic variations, have been mapped. The maps in both atlases are throughoutly commentated. In both atlases, the Finnic language group is divided into seven languages: Finnish, Karelian, Vepsian, 
Votic, Ingrian, Estonian and Livonian ${ }^{2}$. In addition, the material of the North-Estonian and South-Estonian dialect groups, as well as the Karelian dialect groups of Proper-Karelian, Lude (Lyydi) and Olonec (Aunus), have been described separately in ALFE commentaries.

\section{Main mediators of Indo-European loanwords to Finnic}

The earliest Indo-European loanwords were borrowed by ProtoFinnic from Baltic and Germanic languages. It is believed that the earliest contacts between Baltic and Finnic tribes took place in the 2nd millennium B.C. or at the end of the 3rd millennium B.C., while the earliest contacts between Germanic and Finnic tribes took place in the 1st or 2nd millennium B.C. Very early contacts have also been confirmed between Finnic and Slavic tribes (see e.g. Setälä 1913, Thomsen 1931, Kalima 1936 and 1952, and Laanest 1982).

As all the linguistic atlases mentioned above describe the dialect vocabularies of separate Finnic languages, it is possible to follow the post-divisional contacts of each language on their maps. The separate Finnic languages are believed to have emerged at about the beginning of our era. The introduction of Germanic and Slavic (or Old Russian) loanwords into Finnic dialects continued during the 1st millennium A.D. and even later. In the 2nd millennium A.D., the contacts of each Finnic nation with their Indo-European neighbours became more frequent and the main donor languages were Old Swedish and Swedish, Low German and German, Russian and Latvian (see e.g. Ojansuu 1918, Suhonen 1973, Laanest 1982, Rätsep 1983, Vaba 1997, Must 2000 and Metsmägi et al. 2013).

For example, for the 'trousers' Finnic dialects use only Indo-European loanwords. The Finnish housut (and variants) is borrowed from the Old Swedish hosa (SSA 1: 176). The Estonian Pärnumaa dialect word uusad and the Salis Livonian uuzed, uužed were probably influenced by the Estonian Swedish dialect (Ariste 1933: 49, SSA 1: 176, SLW: 212). In some West-Finnish dialects, the Swedish loanword prakut ( $<$ Sw. brackor id.) is used (SKES: 618 ). The Estonian püksid, pöksi(d) came from the Middle Low German boxe, buxe, while the South-Estonian Leivu bikši- and Livonian bikšõd were borrowed via

Different scholars have divided the Finnic branch of the Uralic (Finno-Ugric) languages into six, seven, eight, nine or ten separate languages. The division into seven languages is the most traditional (see e.g. Kettunen 1960, Laanest 1982, Tuomi 2004: 37-41 and Viitso 1985). 
Latvian, cf. Latv. bikses, Finnish pöksyt (a Swedish loan), cf. Sw. byxor (earlier böxor), and from Finnish dialects it was borrowed by Karelian, Ingrian and the Votic Kukkusi dialect (Saareste 1924: 173, SSA 2: 466 and Vaba 1997: 258, EES: 407). Words from two stems were borrowed from Old Russian or Russian. The Finnish kaatiot etc., Karelian koadiet, kuadiet etc., Vepsian kad'g'ad etc., Votic kaatsiat etc. and Estonian kaatsad etc. came from the Old Russian *gatja, cf. Rus. gači (SSA 1: 268, EES: 110). The Karelian, Vepsian and Votic štanat and Karelian štanit (and variants) are new Russian loans $<$ Rus. štany (see Zajceva 2009: 239-243, and ALFE 3: 420-425). The etymology of the Estonian kaltsad (and variants) is obscure, although it has been associated with Slavic (cf. Rus. kološa) and Germanic (cf. MHGm. kalze << MLat. calcia) stems (see e.g. Saareste 1924: 172-173 and EES: 123). The Finnish nouns kalsongit 'long pants' and kalsu, kalso, used in south-east Finnish dialects, and kalsukka in some north-west dialects for leggings came from the same stem (SSA 1: 290 and SMS: 87-88).

The ALFE onomasiologic map describing dialect equivalents for 'goat' illustrates the occurrence of Indo-European loanwords, which belong to eight word families (see Ruoppila 1943: 201-227 and ALFE 3: 138-140). The spread of the word keituri in Finnish dialects spoken in the territories of Sweden and Norway indicates that it is obviously a young Scandinavian loan, cf. OSw. geit (Airila 1936: 240-241, SSA 1: 338). The Finnish kutti and $k u t(t) u$ are considered to belong to the same family as the Swedish kutta (SSA 1: 455 and Häkkinen 2004: 522-523). The Finnish kile variants, as well as the Ingrian and Votic kili and Estonian kilu, are Swedish loans, cf. Sw. kille, killa, kilu (SSA 1: 361). The Estonian kits is a German loan $(<\mathrm{Gm}$. Kitze), while the Ingrian kitsi and Votic kitsi, kittsi were borrowed from the Estonian (EEW: 853, EES: 162). The Livonian tikka, tik(a) is a Middle Low German loan < tike, cf. German Ziege (Kettunen 1938: 420 and Buck 1949: 165). The Finnish vuohi, Ingrian voohi and Votic voho are old Baltic loanwords, cf. OPruss. wosee, Lith. ožkà 'goat', ožỹs 'he-goat' (Kalima 1936: 181, SSA 3: 472). The Karelian, Vepsian and Votic koza is a new loan from the Russian koza, id. The South-Karelian čiba has been recorded in the Karelian dialects spoken in the regions of Tver, Tikhvin and Valdai. The origin of the word is unknown. Perhaps it is an influence from the Russian dialect word cap or its variants, meaning 'he-goat' (Oja 2011: 192). The Russian names for 'he-goat', cap etc., are based on a call for the animal. Similar names occur in Albanian and Romanian dialects (Buck 1949: 165 and Fasmer 4: 288-289). 


\section{One origin - different loans}

Often an Indo-European stem was borrowed by Finnic dialects from different languages. For example, the loanwords for soap with the Germanic origin used in Finnic languages were borrowed in different ways. The Finnish saippua (dial. variants saip(p)io, saip(p)oo, saip(p)aa, saiput etc. $)^{3}$ is a Germanic loan $<$ Gmc. *saipōn (SSA 3: 143). The Ingrian saippu, saippia and Karelian saiput are influences from Finnish. The Estonian seep and Livonian zeep are direct loans from the Low German sepe (SKES: 945, 1009, EEW: 2735, ALFE 1: 203 and EES: 464).

Sometimes the borrowing relations are more complicated and the exact source of a loan is obscure. For example, the Finnic adjectives for 'fresh' derive from seven roots, while south of the Gulf of Finland the prevalent adjectives are loanwords of Low German origin (see ALFE 3: 315-318). The Estonian värske was borrowed directly from the Low German word versch 'fresh' + adjective suffix $-e\left(<*_{-}^{*} e \delta a\right)$ (EEW: 3987, EES: 621). The noun prišs's of the Estonian Leivu dialect spoken in the Latvian territory is a Latvian loan (< Latv. prišs 'fresh'). The Livonian priš (pl.: E-Liv. priššõd, W-Liv. prišiid) was borrowed from German or via Latvian, cf. Latv. prišs ( $<$ German frisch), while the obsolete word veŕšk, pl. veŕškõd of the Kolka dialect might be an Estonian loan (< Est. värske) (Kettunen 1938: 312, 479). The Finnish värski and verski may have been inspired by the Swedish form färsk 'fresh, new' and the Low German word versch, while with ver-initial words one cannot absolutely exclude the possible phonetic influence of the Finnish adjective veres 'fresh', which is derived from the noun veri 'blood' (SKES: 1704-1705).

For 'potato' (Solanum tuberosum), derivatives from kartofel are used in the eastern and southern Finnic languages. The nouns deriving from the German (or Low German) kartuffel or a variant, where the first unstressed syllable has been omitted, tuffel etc., travelled to Finnic dialects by different routes. Estonian and Finnish borrowed the word either directly from Low German or from the (High) German Kartoffel, while the eastern Finnic languages, Karelian and Vepsian, as well as some Finnish and Estonian dialects received the word from Russian, cf. Rus. kartofel', kartoška. The South-Estonian Ludza subdialect, which was spoken in the Latvian territory, borrowed the word

The areal distribution of the dialect variants with different suffixes and phonetic structures of saippua is mapped in ALFE 1: 201-202. 
kartupel from Latvian, cf. Latv. dial. kartupelis (Vaba 1997: 289 and LVDA 111, map 44). The German word Kartoffel originated from the northern Italian tartufolo (a term for a plant with similar tubers as those of the potato), which was first borrowed by the neighbouring German dialects, cf. e.g. Gm. tartoffel, tartuffel etc. in the 16th-18th centuries (Grimm, Grimm, 21: 146, s.v. Tartoffel). While the noun spread into, besides Germanic, mostly Slavic languages, a number of phonetic and morphological changes took place (Škofic 2009: 230231). In Finnic languages, the borrowed stems have produced numerous dialectal variants: Karelian and Vepsian kartohk, kartosk, Finnish kartusk, tarttu, kartooli etc. (for more detail, see ALFE 2: 51, 54-56). Variations of Estonian dialect words are described in the article "Different loan sources as a reason for variability of some Estonian dialect words" (Metsmägi, Sedrik, Oja, this volume).

\section{Some centres and routes of different Indo-European influences in the Finnic area}

We know that the majority of vocabulary innovations follow from cultural contacts. The causes, centres and routes of lexical innovations mostly depend on extra-linguistic factors, such as geographic location, road network, historical and political events, etc. The Finnic peoples lived for a long time under several foreign powers: the Finns were subordinate to Sweden and Russia, the Estonians to Germany, Sweden, Denmark, Poland and Russia, and the Livonians to Germany, Latvia and Russia, while the eastern Finnic territory still belongs to Russia (see e.g. Tuomi 2004).

The wars between the neighbouring countries for domination divided the Finnic areas between eastern and western influences, which can also be seen on several ALE and ALFE maps. In some cases, the boundary separates Finland from the rest of the Finnic area. For example, the ALE onomasiologic map of 'cabbage' shows the spread of two old Indo-European stems in Finnic and neighbouring languages. In Finnish dialects, the words for cabbage come from the same root as in many Germanic and Romance languages (Fin. kaali < Scand., cf. Sw., Norw., Dan. kål, Icel., Ir. kál, Gm. Kohl, Dutch kool, Sp., Cat. col, Port. couve, Fr. chou, etc. $<<$ Lat. caulus, Gr. kaulós etc. 'stalk'), and in other Finnic languages the words come from other roots, e.g. in the eastern areas of European languages, including Slavic and Baltic languages (Kar. kapusta, Veps. kapust, Ing., Vot. kapussa, Est. kaps(t)as 
etc. < Rus. kapusta, cf. Gm. Kappes, Kappus, OGm. capuz, kappaz, Hung. káposzta, Arm., Kalm., Chuv., Udm., Mari etc. $<<$ Lat. caput 'head'); the Livonian kappst was borrowed via Latvian, cf. Latv. kāpuosts, kāpusts, which is also a Russian loan (ALE 1, 7, map 76, and Beltechi and Mocanu 2007: 131-146).

In addition, Finnic terms for 'week' come from two stems: viik- and nedäl- (ALE 1, 6, map 69, and ALFE 1: 301-302). The Scandinavian loanword viikko < Gmc. *wikōn (cf. ONor. vika) is used in Finnish and, as a Finnish loanword, in Ingrian dialects, in the Kukkusi subdialect of Votic and in the Vaivara sub-dialect of Estonian (SKES: 1743, LÄGLOS: 399-400 and SSA 3: 440). In other Finnic dialects, variants of the Russian loanword are used: Karelian netali, netäli, nedäli, neteli (-d-) etc., Vepsian ńedaĺ, Livonian nädiil, Votic näteli, Estonian nädal and other variants < Rus. nedelja 'week', earlier 'Sunday', from Rus. ne delja 'no work' (Fasmer 3: 57 and ALFE 1: 302). A similar Russian loan for 'week' is used in Latvian and in eastern Uralic languages (see ALE 1, 6, map 69, and Humphreys 2002: 170-171).

Often the situation south of the Gulf of Finland is more complicated. For example, for Christmas (ALE I, 5, map 59, Alinei 1997) a Scandinavian loanword is used in Finnish, Ingrian, North-Estonian and in some Votic dialects: Fin., Ing. joulu, Vot. joulu, joulu, N-Est. jõul < Scand., cf. e.g. Dan., Norw., Sw. jul (SKES: 119-120, SSA 1: 243). The South-Estonian and Livonian dialects use old names for the winter solstice: S-Est. tal(v)istepüha, and Liv. pl. talžipivād, which are compounds containing words meaning 'winter-' + 'fest; holiday'. The same process led to the Latvian word for Christmas, cf. Latv. ziemas-, ziem $\mid$ svētki from ziem- 'winter-' + svètki 'fest'. The Russian loanword is used in the eastern part of the Finnic area: Kar. roštuo, roštova, Veps. raštvad, raštā, Vot. räštoga räštogo < Rus. roždestvo from Rus. rodit' 'give birth (to)'. From Russian, there is also > Lap. rosttov, Udm., Mari, KomZyr., EMd., MMd. and the Tatar roždestvo.

Next, some essential contacts of Finnic peoples with three main donor languages will be briefly described.

\subsection{Swedish loans}

On ALE and ALFE maps, we can see that many Indo-European stems have been mediated to Finnish via Swedish. For centuries, Swedish colonists were in a privileged position in Finland, and Swedish 
was the language of commerce, the courts and education there (Tarkiainen 2010). Estonia had its closest contacts with Swedes in the 16th and 17th centuries. In the Middle Ages the coasts and islets of Finland and Estonia were populated by Swedes (see e.g. Ariste 1933: 1-2 and Blumfeldt 1961). Their dialects, called Finland-Swedish and Estonian-Swedish, belonging to the East Swedish dialect group, have preserved some archaic phenomena compared with standard modern Swedish. Finland-Swedish dialects are spoken by Swedish settlements in southern and western coastal areas of Finland today, but the Swedish area was larger earlier (see e.g. OFSF: VIII-XVIII). Under such conditions it is understandable that Finnish has a lot of Swedish loans.

A great number of Swedish loanwords are used all over Finland, not only in coastal dialects. For example, puska 'bush' $(<\mathrm{Sw}$. dial. buska, cf. Sw. buske, Norw. buska, busk, Dan. busk, LGm. pusch, busch) is used widely in Finnish dialects (see map 1; ALFE 2: 92-97). For some terms, Finnish dialects use several Swedish loans, e.g. the above-mentioned keituri, kuttu, kile 'goat' and housut, prakut 'trousers'. A noun with a pota- stem, meaning 'potato', came into the Finnish dialects through Swedish, cf. Sw. potatis (dial. potata), where it is an English loan (Hellquist 1922: 593, Buck 1949: 374 and SSA 2: 404). The loanwords pota(a)tti, potakka, pottu, poteri etc. are used mainly in EastFinnish dialects, in the Häme dialect and in the northern regions of Finland and Karelia. The West-Finnish word for 'potato', peruna, peru, perna, pärnä etc., is also a Swedish loanword, cf. Sw. päron meaning 'pear' ( $<<$ Lat. pirum id.), jordpäron 'potato' (literally 'pear of the earth') (SSA 2: 342, ALFE 2: 48). The ALE and ALFE maps make it clear that one important route by which many Scandinavian loanwords spread to Finnish is the Gulf of Bothnia. Along the Oulu River, which flows into the gulf, the loanwords found their way into the surrounding areas and into the south-east dialects.

In Estonian dialects, most of the Swedish loans occur in the coastal areas and in the western Estonian islands (Ariste 1933, Raag 1988). Words of Swedish origin may have been borrowed by Estonian dialects in different ways: from Sweden-Swedish or Estonian-Swedish or Finland-Swedish or via Finnish dialects, e.g. the Swedish loanwords for some boats (Neetar and Oja 2007). The geographical distribution of a word is one of the main characteristics used to determine its exact source (for more detail, see Raag 1997). 


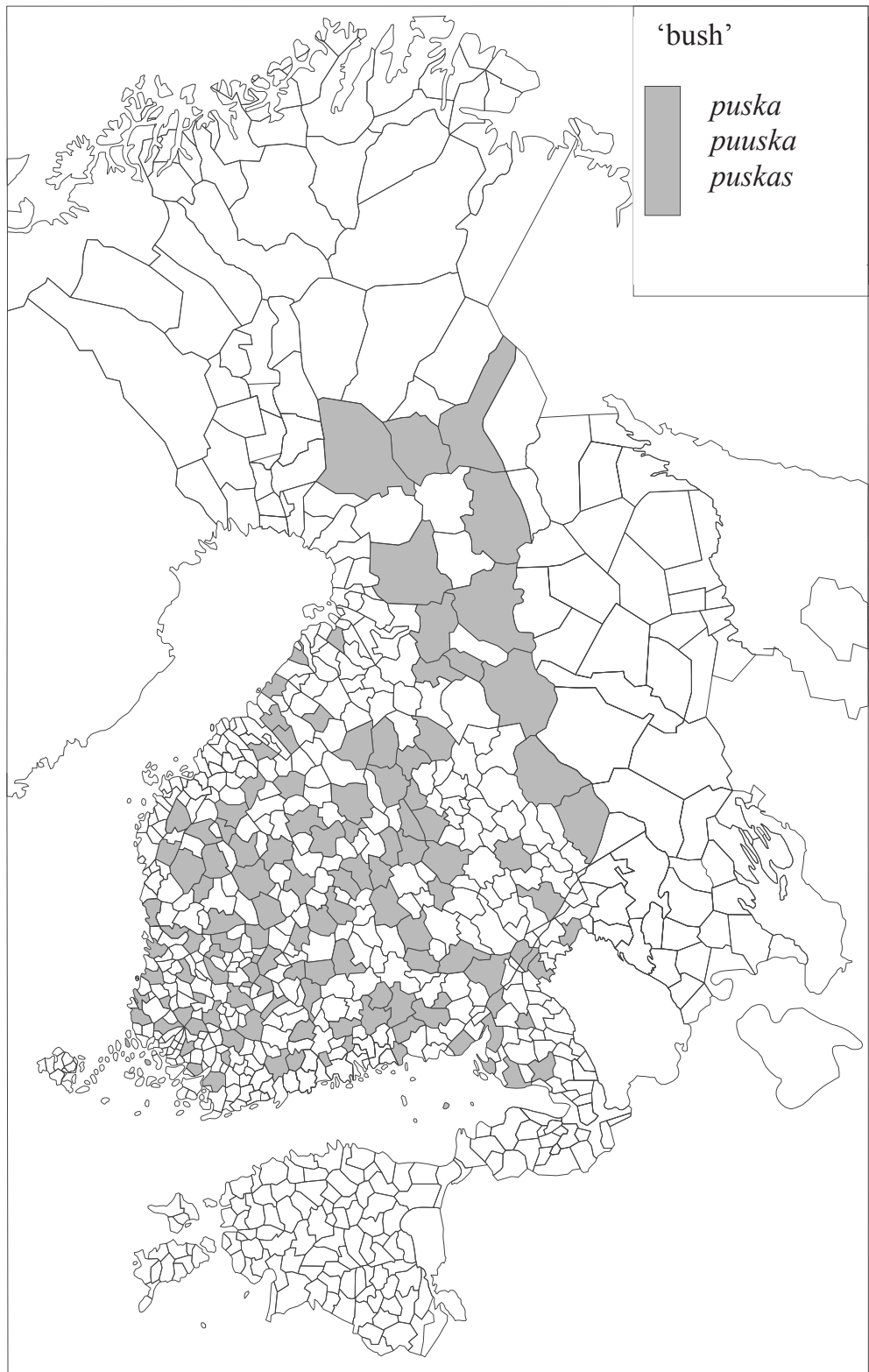

Map 1. puska variants for 'bush' in Finnic dialects, according to ALFE mapping points. 


\subsection{German and Low German loans}

In Estonian and Livonian, there are a large number of German and Low German loans (see e.g. Ariste 1972, Rätsep 1983 and Metsmägi et al. 2013). For example, the ALE material on 'ink' (ALEQ, question No. 498) indicates that ink is tint in Estonian and Livonian, while the other Finnic languages use other words. In the German-speaking area, Tinte variants dominate (earlier tincte, tincta, dincta), going back to the Latin tincta (aqua) 'coloured (water)'. From German, Tinte spread to a number of languages, including the Lithuanian tinta, Latvian tinte, and Livonian and Estonian tint (Grimm, Grimm 21: 146, s.v. Dinte, and Viereck 2011: 25). The situation where a word of Germanic origin was borrowed by Estonian and Livonian from (Low) German, but by Finnish from Swedish can also be seen on ALE and ALFE maps, e.g. verski / värske 'fresh' and saippua / seep 'soap' mentioned above. Various maps show different equivalents for a concept where the majority of Finnish dialects use several Swedish loanwords (e.g. housut and prakut 'trousers'; nouns from the pota- and peru- stem 'potato'), but Estonian, especially North-Estonian dialects, uses mainly German loans (variants of püksid 'trousers'; kartul, tuhvel etc. 'potato').

Unlike the loanwords of Germanic origin used in Estonian, Livonian and Finnish, often Russian loanwords are used in the eastern Finnic languages. For example, the Estonian kamm g. kammi 'comb' is a German loan $<\mathrm{Gm}$. Kamme (EES: 125) and the Livonian kämm käm $\sim k^{\prime} e m$, kemm is of Low German origin < LGm. kämm, or was borrowed via Latvian, cf. Latv. kemme (SLW: 97), while the Finnish kampa g. kamman 'id.' was borrowed from Scandinavia, cf. ONor. kambr, Sw. kam, dial. kamba (SKES: 153, SSA 1: 295). Other Finnic languages use a Russian loan, Ing. greeveńi, griepeni, kriepina, Vot. greebeni, Kar. grebjonka etc. (< Rus. greben' 'id.'), or an old noun from the stem *śúka-, meaning various combs and brushing tools, e.g. Ing., Veps. suga, Kar. suga, suka (š-), Vot. suka (Nirvi 1971: 39, 206, 547, KKS 2: 371, 536, SSA 3: 209, ALE 1, 7, map 78, Siatkowski 2007, and VKS: 236, 1179).

Many German innovations came into Estonian and Livonian during trade contacts. From the 13th till the 16th century the trade across the Baltic Sea and North Sea was controlled by the Hansa League, containing nine Circles. For Finnic people, the most important was the Livonian Circle, situated on the east coast of the Baltic Sea. In Estonia and Livonia, there were three big Hansa trading cities - Riga, Tallinn and Tartu - and a dozen smaller ones, which were important centres 
of transit trade between Russia and western Europe. Also, these were centres of innovation and language contacts, where many loanwords came into Estonian, from where they spread into other Finnic languages. In 15th-century Finland, there were only two Hansa trading posts (Kontors), Turku (Åbo) and Viipuri (Vyborg). All this has left its traces in vocabularies.

\subsection{Russian influences}

Most Russian loanwords are used in Karelian and Vepsian dialects. A great number of Russian loanwords can also be found in Votic and Ingrian dialects. An interesting example of several Russian influences is the spread of the verbs meaning 'to be ill' or 'being ill' in eastern Finnic dialects (see map 2). The Karelian boleida, boleija, bolie came from the Russian bolet' 'ache; to be ill', and the verb läsie, läžiä etc. is borrowed from the Russian ležat', literally 'to lay up', also used in the meaning 'to be ill'. Variants of Karelian ei voi and Vepsian iivida are loan translations from the Russian nemoč', (emu) nemožetsja 'to be ill, (he/she) is ill; to be sick or unwell, (he/she) is sick or unwell' (Laanest 2000: 38-43, ALFE 2: 413-416).

Many Russian loans are also used in Finnish, mostly in southeastern dialects, e.g. kartusk 'potato' and kaatiot 'trousers', mentioned above. Some Russian loans are more widespread. A typical East-Finnic word is vasta 'sauna whisk' < ORus. hvostŭ 'tail', cf. Rus. verb hvostat' (SSA 3: 416). Sauna whisk is vasta in Karelian, Vepsian, Ingrian and the East-Finnish dialect group, but also in northern Ostrobothnian dialects (Leskinen 1992: 56, ALFE 1: 176-177). The Finnish term sukkula 'shuttle' is considered to be an Old Russian loan, cf. Rus. skal'ja, Ukr. sukalo (Kalima 1952: 162-163, SKES: 1098, and SSA 3: 210). Word variants from the sukkul- stem are used in Karelian, Vepsian, Ingrian, in some dialects of the North-Estonian coastal group and in most Finnish dialects (Leskinen 1992: 52-53, ALFE 3: 400406).

An important medieval trade and communication centre of ancient Karelia was Korela (Swedish Kexholm, Finnish Käkisalmi) on the Karelian Isthmus, on the north-western coast of Lake Ladoga, on the Vyborg-Novgorod trading route. In some cases, innovations spread from the Karelian Isthmus far to the north-west, into eastern Finnish dialects (see e.g. Leskinen 1992: 3 and Tuomi 2009: 255-257). 


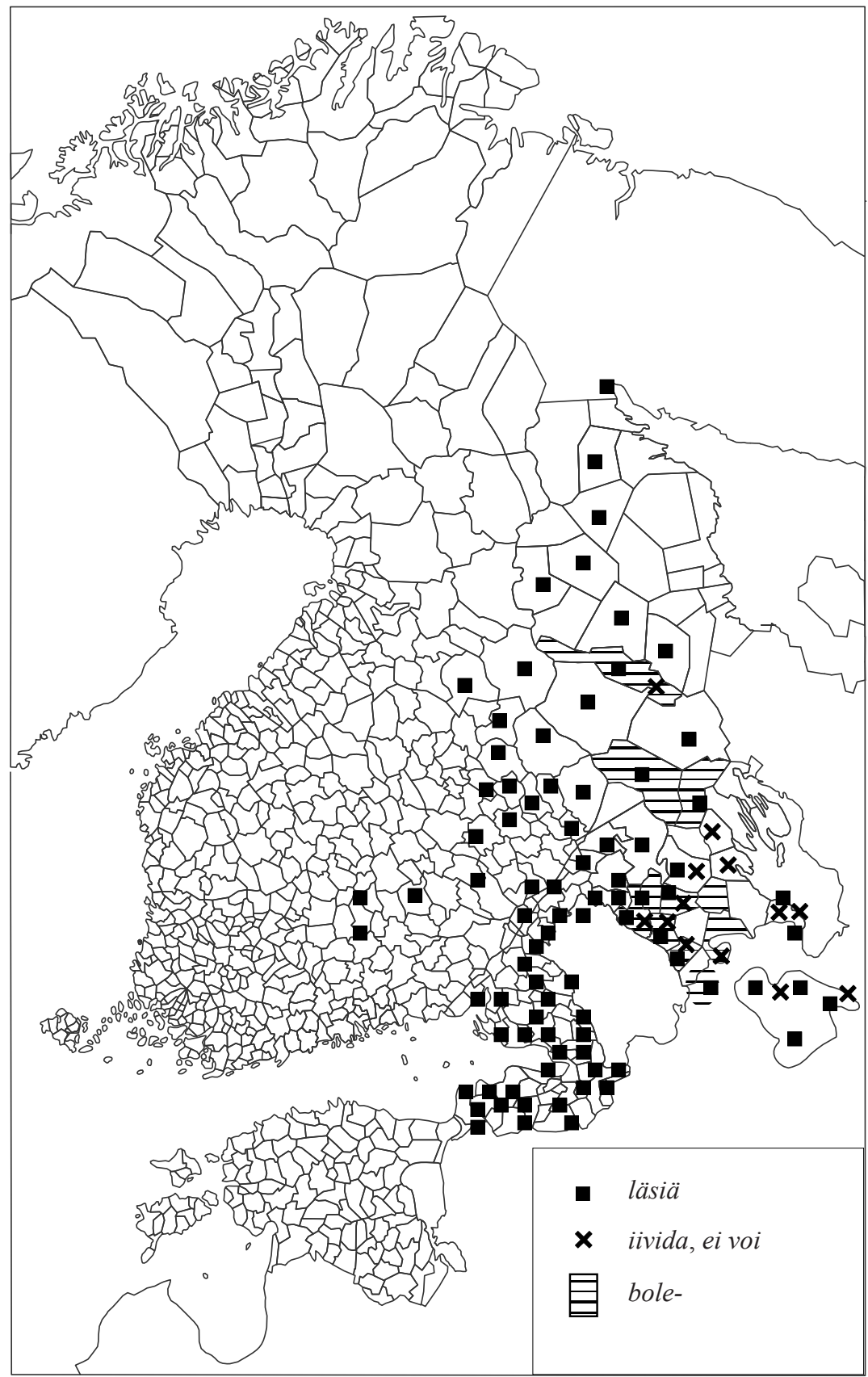

Map 2. 'to be ill' Russian loans in Finnic dialects. 


\section{Conclusion}

Finnic contacts with neighbouring languages are vividly shown on the maps of the Atlas Linguarum Fennicarum and the Atlas Linguarum Europae. It is common that Indo-European loanwords arrived in different Finnic languages from different directions, as different superpower relations led to different patterns of bilingualism and different extents of changes that the languages witness. For Finnish, the main source language has been Swedish, for Estonian - German or Low German, for Livonian - Low German and Latvian, and for eastern Finnic languages (primarily Karelian and Vepsian) - Russian. Nevertheless, as can be seen in the maps of these atlases, Estonian has also adopted a lot of Swedish, Russian and Latvian loanwords, Finnish has many Russian words, and Karelian, Ingrian and Votic dialects use many words originating from the same Germanic stem as in Finnish or Estonian.

The majority of the lexical maps of ALFE and ALE demonstrate that the boundaries of areas of the spread of dialect words do not coincide with the boundaries of languages. The distribution of dialect words is one of the criteria in deciding the source of borrowing. For instance, some originally Swedish words may have reached Estonian, Karelian, Ingrian and Votic via Finnish, not directly from Swedish, some German loanwords have reached Ingrian and Votic via Estonian or Finnish, and some German and Russian loans have entered Livonian via Latvian. The source language depends, of course, on the concept, as well as on the time of borrowing. Status factors between the languages in contact have also been important. Often an Indo-European stem has been mediated to Finnic dialects repeatedly from different languages, or in different periods.

The spread of loanwords also shows the main centres and routes of lexical innovations, which have often depended on extra-linguistic factors. Many contacts between Finnic and Indo-European peoples have been in connection with trade. Important centres of innovation and of language contacts were Hansa cities and trading posts on the territory of Estonia and Livonia, the ancient trade centre Korela on the northwestern coast of Lake Ladoga, and ports on the Gulf of Bothnia. Many Indo-European loanwords reached these centres, from where they were distributed to other Finnic dialects.

In many maps of ALE and ALFE, the east-west opposition is exemplified. According to loanwords, usually Finnish belongs to the sphere of western influences, while Karelian and Vepsian dialects have more 
eastern influences. As for Estonian and Livonian dialects, some borrowings associate them with the western, and some others with the eastern sphere of influence. The most complex linguistic relations involve Ingrian and Votic, which have been subjected to the crossinfluences of three higher-prestige neighbouring languages: Finnish, Estonian and Russian. Some ALE maps reveal that the Finnic area has been a peripheral meeting place of several widespread Indo-European words arriving from different directions.

\title{
Acknowledgements
}

For the financing of the study, I would like to express my gratitude to the Estonian Ministry of Education and Research (SF0050037s10) and the Estonian Science Foundation (ETF9367).

\author{
Address: \\ Vilja Oja \\ Institute of the Estonian Language \\ Roosikrantsi 6 \\ 10119 Tallinn, Estonia \\ Vilja.Oja@eki.ee
}

\section{Abbreviations}

Arm. - Armenian, BRus. - Belorussian, Cat. - Catalan, Chuv. Chuvash, Dan. - Danish, E-Liv. - East-Livonian, EMd. - ErzyaMordvin, Est. - Estonian, Fin. - Finnish, Fr. - French, Gm. - German, Gmc. - Germanic, Gr. - Greek, Hung. - Hungarian, Ing. - Ingrian, Ir. - Irish, Icel. - Icelandic, Kalm. - Kalmyk, Kar. - Karelian, KomZyr. - Komi-Zyryan, Lap. - Lappish (Saami), Lat. - Latin, Latv. Latvian, LGm. - Low German, Lith. - Lithuanian, Liv. - Livonian, MHGm. - Middle High German, MLat.- Middle Latin, MMd. Moksha-Mordvin, N-Est. - North-Estonian, Norw. - Norwegian, OGm. - Old German, ONor. - Old Norse, OPruss. - Old Prussian, ORus. Old Russian, OSw. - Old Swedish, Port. - Portuguese, Rum. Rumanian, Rus. - Russian, Scand. - Scandinavian, S-Est. - SouthEstonian, Sp. - Spanish, Sw. - Swedish, Udm. - Udmurt, Ukr. Ukrainian, Veps. - Vepsian, Vot. - Votic, W-Liv. - West-Livonian 


\section{References}

Airila, Martti (1936) "Suomen keituri”. Virittäjä 3, 240-241.

ALE = Atlas Linguarum Europae. Commentaires. Cartes. Volume I, f. 1-4 Assen, Maastricht: Van Gorcum 1983-1990, f. 5-7 Roma: Istituto Poligrafico e Zecca dello Stato 1997-2007, f. 8 Bucureşti: Editura Universităţii din Bucureşti 2014.

ALEQ = Atlas Linguarum Europae. Premier Questionnaire, Onomasiologie. Eds. Antonius Angelus Weijnen, et al. Vocabulaire fondamental préparé par Joep Kruijsen. Assen: Van Gorcum 1976.

ALFE = Atlas Linguarum Fennicarum. Itämerensuomalainen kielikartasto. Läänemeresoome keeleatlas. Ostseefinnischer Sprachatlas. Lingvističeskij atlas pribaltijsko-finskix jazykov. ALFE 1-3. Editor-in-chief Tuomo Tuomi. Edited by: Seppo Suhonen (part 1), Tiit-Rein Viitso (part 2), Vladimir Rjagojev (part 3). (Suomalaisen Kirjallisuuden Seuran Toimituksia, 800/1295. Kotimaisten kielten tutkimuskeskuksen julkaisuja, 118/159.) Helsinki: Suomalaisen Kirjallisuuden Seura, Kotimaisten kielten tutkimuskeskus 2004-2010.

Alinei, Mario (1997) "Noël, roždestvo, christmas, Weihnachten, navidad, natale”. In ALE I, 5. Commentaires, 253-291.

Ariste, Paul (1933) Eesti-rootsi laensõnad eesti keeles. (Acta et Commentationes Universitatis Dorpatensis. B XXIX, 3.) Tartu.

Ariste, Paul (1972) "Das Niederdeutsche im Estnischen". Sovetskoe finno-ugrovedenie VIII, 2, 91-99.

Beltechi, Eugen and Nicolae Mocanu (2007) "Chou, cabbage, kohl, col, cavolo". In ALE I, 7. Commentaires, 131-146.

Blumfeldt, Evald (1961) "Estlandssvenskarnas historia". In En bok om Estlands svenskar I, 63-178. Stockholm: Kulturföreningen Svenska Odlingens Vänner.

Bubrih, D. V., A. A. Beljakov and A. V. Punžina (1997) Dialektologičeskij atlas karel'skogo jazyka. Karjalan kielen murrekartasto. Venäjän tiedeakatemian Karjalan tiedekeskuksen Kielen, kirjallisuuden ja historian instituutti. Kotimaisten kielten tutkimuskeskus. Editor Leena Sarvas. (Kotimaisten kielten tutkimuskeskuksen julkaisuja, 97.) Helsinki: Suomalais-Ugrilainen Seura.

Buck, Carl Darling (1949) A dictionary of selected synonyms in the principal IndoEuropean languages. A contribution to the history of ideas. Chicago, Illinois: The University of Chicago Press.

EES = Metsmägi, Iris, Meeli Sedrik and Sven-Erik Soosaar (2012) Eesti etümoloogiasõnaraamat. Eesti Keele Instituut. Tallinn: Eesti Keele Sihtasutus.

EEW = Mägiste, Julius (1982-1983) Estnisches etymologisches Wörterbuch. Helsinki: Finnisch-Ugrische Gesellschaft.

EMA $=$ Saareste, Andrus $(1938,1941)$ Eesti murdeatlas. Atlas des parlers estoniens. I (maps 1-28), II (maps 29-66). Tartu.

EMSUKA $=$ Eesti murrete ja soome-ugri keelte arhiiv (Archive of Estonian dialects and Finno-Ugric languages). Institute of the Estonian Language, Tallinn. 
Fasmer, Maks (1976) Ėtimologičeskij slovar' russkogo jazyka 1-4. Perevod s nemeckogo i dopolnenija člena-korrespondenta AN SSSR O. N. Trubačeva. Pod redakciej i s predisloviem B. A. Larina. Izdanie vtoroe, steretipnoe. Moskva: Progres.

Grimm, Grimm = Jacob Grimm and Wilhelm Grimm 1854-1960. Das deutsches Wörterbuch von Jacob und Wilhelm Grimm [in 32 Teilbänden]. Leipzig: S. Hirzel, auf CD-ROM und im Internet. Ein Projekt des Kompetenzzentrums für elektronische Erschließungs- und Publikationsverfahren in den Geisteswissenschaften an der Universität Trier in Verbindung mit der Berlin-Brandenburgischen Akademie der Wissenschaften Berlin. Available online at $<$ http://woerterbuchnetz.de/DWB/>. Accessed on 20.07.2014.

Hellquist, Elof (1922) Svensk etymologisk ordbok. Lund: Gleerups.

Humphreys, Lloyd Humphrey (2002) "Semaine, nedelja, week, Woche, Semana, Settimana". In ALE I, 6. Commentaires, 161-176.

Häkkinen, Kaisa (2004) Nykysuomen etymologinen sanakirja. Juva: WSOY.

IMSK = Itämerensuomalainen kielikartasto. Kyselysarja . Kotimaisten kielten tutkimuskeskus. Helsinki 1989.

Kalima, Jalo (1936) Itämerensuomalaisten kielten balttilaiset lainasanat. (Suomalaisen Kirjallisuuden Seuran Toimituksia, 202.) Helsinki: Suomalaisen Kirjallisuuden Seura.

Kalima, Jalo (1952) Slaavilaisperäinen sanastomme. Tutkimus itämerensuomalaisten kielten slaavilaisperäisistä lainasanoista. (Suomalaisen Kirjallisuuden Seuran Toimituksia, 243.) Helsinki: Suomalaisen Kirjallisuuden Seura.

Kettunen, Lauri (1938) Livisches Wörterbuch mit grammatischer Einleitung. (Lexica Societatis Fenno-Ugricae, V.) Helsinki: Suomalais-Ugrilainen Seura.

Kettunen, Lauri (1940) Suomen murteet III. A. Suomen murrekartasto, B. Selityksiä murrekartastoon. (Suomalaisen Kirjallisuuden Seuran Toimituksia, 188.) Helsinki: Suomalaisen Kirjallisuuden Seura.

Kettunen, Lauri (1960) Suomen lähisukukielten luonteenomaiset piirteet. (SuomalaisUgrilaisen Seuran Toimituksia, 119.) Helsinki: Suomalais-Ugrilainen Seura.

KKS $=$ Karjalan kielen sanakirja 2. (Lexica Societatis Fenno-Ugricae, XVI, Kotimaisten kielten tutkimuskeskuksen julkaisuja, 25.) Helsinki: Suomalais-Ugrilainen Seura, 1974.

Laanest, Arvo (1982) Einführung in die ostseefinnischen Sprachen. Autorisierte Übertragung aus dem Estnischen von Hans Hermann Bartens. Hamburg: Helmut Buske Verlag.

Laanest, Arvo (2000) "Käsitteet 'sairastaa' ja 'rukoilla"'. In Studia ad geographiam linguarum pertinentia. Edited by Vilja Oja and Seppo Suhonen, 38-49. (Eesti Keele Instituudi toimetised, 6.) Tallinn: Eesti Keele Sihtasutus.

Leskinen, Heikki (1992) Karjalan kielikartasto I. Idän ja lännen sanastoeroja. (Jyväskylän yliopiston suomen kielen laitoksen julkaisuja, 35.) Jyväskylä: Jyväskylän yliopisto. 
LVDA = Latviešu valodas dialektu atlants: leksika. The Dialectal Atlas of Latvian: Vocabulary. Dialektologičeskij atlas latyšskogo jazyka: leksika. Latvijas Zinātņu Akadēmija, Latviešu valodas institūts, Literatūras, folkloras un mākslas institūts. Rīgā: Zinātne, 1999.

LÄGLOS = Kylstra, A. D., Sirkka-Liisa Hahmo, Tette Hofstra and Osmo Nikkilä (2012) Lexikon der älteren germanischen Lehnwörter in den ostseefinnischen Sprachen 3. Amsterdam-Atlanta-New York: Rodopi.

Metsmägi, Iris, Meeli Sedrik and Sven-Erik Soosaar (2013) "Eesti kirjakeele tüvevara päritolu arvudes". Keel ja Kirjandus 5, 313-332.

Must, Mari (2000) Vene laensõnad eesti murretes. Tallinn: Eesti Keele Sihtasutus.

Neetar, Helmi and Vilja Oja (2007) "Some Swedish loanwords for boats in Estonian dialects". Från drasut till brakknut. Studier tillägnade Gerd Eklund på 65årsdagen. Editor-in-chief Maj Reinhammar, edited by Lennart Elmevik, Kristina Hagren, 147-156. (Meddelanden från Sällskapet för svensk dialektologi, 1.) Uppsala: Uppsala Universitet.

Nirvi, Ruben Erik (1971) Inkeroismurteiden sanakirja. (Lexica Societatis FennoUgricae, XVIII.) Helsinki: Suomalais-Ugrilainen Seura.

OFSF $=$ Ordbok över Finlands svenska folkmål. I (A - E). Forskningscentralen för de inhemska språken. Editor Olav Ahlbäck. Helsingfors: Svenska litteratursällskapet i Finland, 1982.

Oja, Vilja (2011) "Innovations in Finnic as reflected on linguistic maps". In Congressus XI. Internationalis Fenno-Ugristarum Piliscsaba, 9-14. VIII. 2010. Pars VI, Dissertationes symposiorum ad linguisticam. Eds. Sándor Csúcs, Nóra Falk, Viktória Tóth, Gábor Zaicz, 189-196. Piliscsaba: Reguly Társaság.

Ojansuu, Heikki (1918) "Altes und Neues zu den germanisch-finnischen Berührungen". Neuphilologische Mitteilungen 19, 49-61.

Raag, Raimo (1988) "Nunn, prilla, koka ja teised. Eesti keele rootsi laensõnadest". Keel ja Kirjandus 11-12, 655-664, 725-732.

Raag, Raimo (1997) “Criteria for establishing lexical borrowings in Estonian”. In Finnisch-ugrische Sprachen in Kontakt. Vorträge des Symposiums aus Anlaß des 30-jährigen Bestehens der Finnougristik an der Rijksuniversiteit Groningen 21.23. November 1996. Edited by Sirkka-Liisa Hahmo, Tette Hofstra, László Honti, Paul van Linde, and Osmo Nikkilä, 185-190. Maastricht: Shaker.

Ruoppila, Veikko (1943) Kotieläinten nimitykset suomen murteissa I. (Suomalaisen Kirjallisuuden Seuran Toimituksia, 222.) Helsinki: Suomalaisen Kirjallisuuden Seura.

Rätsep, Huno (1983) “Eesti tüvevara päritolu”. Keel ja Kirjandus 10, 539-548.

Saareste, Albert (1924) Leksikaalseist vahekordadest eesti murretes I. Analüüs 60 kaardi ja 1 skeemiga. (Acta et Commentationes Universitatis Dorpatensis. B VI, 1.) Tartu.

Setälä, Emil Nestor (1913) "Beiträge zu den germanischen Wörtern im finnischen und ostseefinnischen”. Finnisch-Ugrische Forschungen XIII, 313-475. 
Siatkowski, Janusz (2007) "Peigne, grebeń, comb, Kamm, peine, pettine". In ALE 1, 7. Commentaires, $155-168$.

SKES = Erkki Itkonen, Yrjö H. Toivonen and Aulis J. Joki (1955-1981) Suomen kielen etymologinen sanakirja. I-VII. (Lexica Societatis Fenno-Ugricae, XII, 2, Tutkimuslaitos "Suomen Suvun" julkaisuja, III.) Helsinki: Suomalais-Ugrilainen Seura.

SLW = Salis-Livisches Wörterbuch. Herausgegeben von Eberhard Winkler und Karl Pajusalu. Tallinn: Teaduste Akadeemia Kirjastus, 2009.

SMS = Suomen murteiden sanakirja, 6. (Kotimaisten kielten tutkimuskeskuksen julkaisuja, 36.) Helsinki: Kotimaisten kielten tutkimuskeskus, Edita, 1999.

SMSA $=$ Suomen murteiden sanaarkisto (Lexical Archive of Finnish Dialects). Institute for the Languages of Finland, Helsinki.

SSA = Suomen sanojen alkuperä. Etymologinen sanakirja. Edited by E. Itkonen, U.-M. Kulonen. (Suomalaisen Kirjallisuuden Seuran Toimituksia, 556; Kotimaisten Kielten Tutkimuskeskuksen Julkaisuja, 62.) Helsinki: Suomalaisen Kirjallisuuden Seura, Kotimaisten Kielten Tutkimuskeskus, 1992-2000.

Suhonen, Seppo (1973) Die jungen lettischen Lehnwörter im Livischen. (SuomalaisUgrilaisen Seuran Toimituksia, 154.) Helsinki: Suomalais-Ugrilainen Seura.

Škofic, Jožica (2009) "Words for potato in Finnic languages in Atlas Linguarum Europae". In Kodukeel ja keele kodu. Home language and the home of a language. Edited by Marja Kallasmaa and Vilja Oja, 225-236. (Eesti Keele Instituudi toimetised, 13.) Tallinn: Eesti Keele Sihtasutus.

Tarkiainen, Kari (2010) Ruotsin Itämaa. Esihistoriasta Kustaa Vaasaan. Suomen ruotsalainen historia 1. (Skrifter utgivna av Svenska litteratursällskapet i Finland, 702:1.) Helsingfors: Svenska litteratursällskapet i Finland.

Thomsen, Vilhelm (1931) Berührungen zwischen den finnischen und den baltischen (litauisch-lettischen) Sprachen. Eine sprachgeschichtliche Untersuchung. (Samlede Afhandlinger, IV.) København: Nordisk Forlag.

Tuomi, Tuomo (2004) “Einführung”. In ALFE 1, 37-52.

Tuomi, Tuomo (2009) "Itämerensuomalaisten kielten sanastollisista innovaatiokeskuksista". In Kodukeel ja keele kodu. Home language and the home of a language. Edited by Marja Kallasmaa and Vilja Oja, 251-264. (Eesti Keele Instituudi toimetised, 13.) Tallinn: Eesti Keele Sihtasutus.

Vaba, Lembit (1997) Uurimusi läti-eesti keelesuhetest. Eesti Keele Instituut. Tampereen yliopiston suomen kielen ja yleisen kielitieteen laitos. Tallinn, Tampere.

VEMA = Saareste, Andrus (1955) Väike eesti murdeatlas. Petit Atlas des parlers estoniens. (Skrifter utgivna av Kungl. Gustav Adolfs Akademien, 28.) Uppsala: Almqvist \& Wiksells.

Viereck, Wolfgang (2011) "The Atlas Linguarum Europae: A diachronic analysis of its data”. In Corpus-based analysis and diachronic linguistics. Edited by Yuji Kawaguchi, Makoto Minegishi and Wolfgang Viereck, 21-36. (Studies in Linguistics, 3. Tokyo University of Foreign Studies, University of Bamberg.) John Benjamins. 
Viitso, Tiit-Rein (1985) "Kriterien zur Klassifizierung der Dialekte der ostseefinnischen Sprachen". In Dialectologia Uralica. Materialen des ersten Internationalen Symposions zur Dialektologie der uralischen Sprachen 4.-7. September 1984 in Hamburg. Herausgegeben von W. Veenker, 89-96. (Veröffentlichungen der Societas Uralo-Altaica, 20.) Wiesbaden: Harrassowitz.

VKS = Vadja keele sõnaraamat. Vad'd'aa tšeelee sõna-tširja. Slovar'vodskogo jazyka. 2nd, supplemented and revised edition. Editors of the 1st edition Elna Adler, Silja Grünberg and Merle Leppik. Editor-in-chief Valmen Hallap. Editor of the 2nd edition Silja Grünberg. Eesti Keele Instituut. Tallinn: Eesti Keele Sihtasutus, 2013.

Zajceva, Nina (2009) "Pari pientä kuvaa aineellisesta ja henkisestä elämästä ALFEn peilaamana ('housut', 'susi')". In Kodukeel ja keele kodu. Home language and the home of a language. Edited by Marja Kallasmaa and Vilja Oja, 237-249. (Eesti Keele Instituudi toimetised, 13.) Tallinn: Eesti Keele Sihtasutus.

Kokkuvõte. Vilja Oja: Indoeuroopa laensõnade levikust läänemeresoome keelte murretes. Kõigi läänemeresoome keelte murdesõnu koos on kaardistatud keeleatlastes "Atlas Linguarum Fennicarum" ja "Atlas Linguarum Europae". Murdesõnade levilad ei kattu enamasti keelealadega. Atlaste kaartidel näeme alasid, kus eesti murretes on levinud (alam)saksa, rootsi, läti ja vene laensõnad, soome murretes rootsi ja vene laenud ning isuri, vadja, karjala ja vepsa keeles vene laenud või samad germaani algupäraga sõnad nagu soome või eesti keeles. Palju indoeuroopa laene seostub kaubandussuhetega ja siinmail valitsenud võõrvõimudega. Laenuallika määratlemisel arvestatakse sõna sisu ja laenamise aega. Osa rootsi sõnu on eesti, karjala, isuri ja vadja murretesse laenatud soome keelest. Saksa sõnu on isuri ja vadja murretesse levinud soome ja eesti keelest. Saksa laenudel liivi keeles leidub lätipäraseid jooni. Sõnalevikud näitavad, et soome keel kuulub sagedamini lääne, karjala ja vepsa murded ida mõjusfääri. Eesti ja liivi keeles on laene mõlemast suunast. Isuri ja vadja murretes kajastuvad kolme naaberkeele soome, eesti ja vene mõjutused.

Märksõnad: murdesõnavara, indoeuroopa laenud, keeleatlased, läänemeresoome keeled 